\title{
Rhythm in Motion: developing English skills through music and creative movement
}

\author{
运动中的节奏 : 通过音乐和创造性动作发展英语技能 \\ Dr. Rachel Sweeney \\ Liverpool Hope University, November 2019
}

\begin{abstract}
In August 2015 a group of seven students and staff from Liverpool Hope University in the UK visited the SOS Children's Village just outside Galle town in Southern Sri Lanka, to partake in a two week residential program 'Global Hope', teaching English to children between four and fifteen. Below is lecturer Dr Rachel Sweeney’s account of their experiences at the SOS Village, reflecting on a range of somatic educational tools as applied to the pedagogic focus of teaching English through movement and music, and focusing broadly on the education values of somatics as placed within an interdisciplinary embodied approach. The paper will follow the pedagogic approach to teaching English through creative play, where the emphasis is on inclusivity and individual agency, allowing for more receptive learning through familiarity with lessons often centred around rhythmic exercises that emphasise repetition through call and response alongside gestural movement and song. These learning practices follow a constructivist approach to pedagogy where the physical embodiment of the image or word allows children to take ownership over their learning, while engaging widely with each other as also the young student teachers. In presenting an extended case study of the above creative arts programs that are designed to prioritise kinaesthetic learning methods whilst implementing English speaking and writing skills, this paper will also engage with a wider political overview of the Centre's mission aims, which respond to the vast spectrum of southern Sri Lanka's social and economic problems.
\end{abstract}

Keywords: creative pedagogy, kinaesthetic learning, language skills, ecology, rhythmic training

\section{摘要}

2015年8月，来自英国利物浦赫普大学的学生和教职人员一行7人参观了斯里兰卡南部 加勒镇郊外的SOS儿童村，参加为期两周的住宿计划 “全球希望”，教授四岁到十五岁 的儿童英语。以下是讲师Rachel Sweeney博士对他们在SOS村经历的描述，对一系列 侧重使用动作和音乐进行英语教学的身心教育工具进行了反思，聚焦于跨学科具身教学 法中身心学广泛的教育价值。本文将采用创造性游戏的教学方法教授英语，强调包容性 和个体能动性，考虑到更具接受性的学习方式，通常结合手势与歌曲，以相互应答的方 式进行节奏练习，强调重复性，以此熟悉课文。这些学习实践遵循建构主义的教学法， 其中以肢体具身化的方式体验图像或单词允许孩子们自主学习，同时也与年轻的实习老 师大量地互动。本文除了介绍一个运用上述创造性艺术课程的具体案例，旨在展示优先 运用动觉学习方法，教授英语口语和写作技能的方式，还将从政治层面概述该项目中心 的使命目标，以应对斯里兰卡南部广泛层面的社会和经济问题。

关键词 : 创造性教学法，动觉学习，语言技巧，生态学，节奏训练 


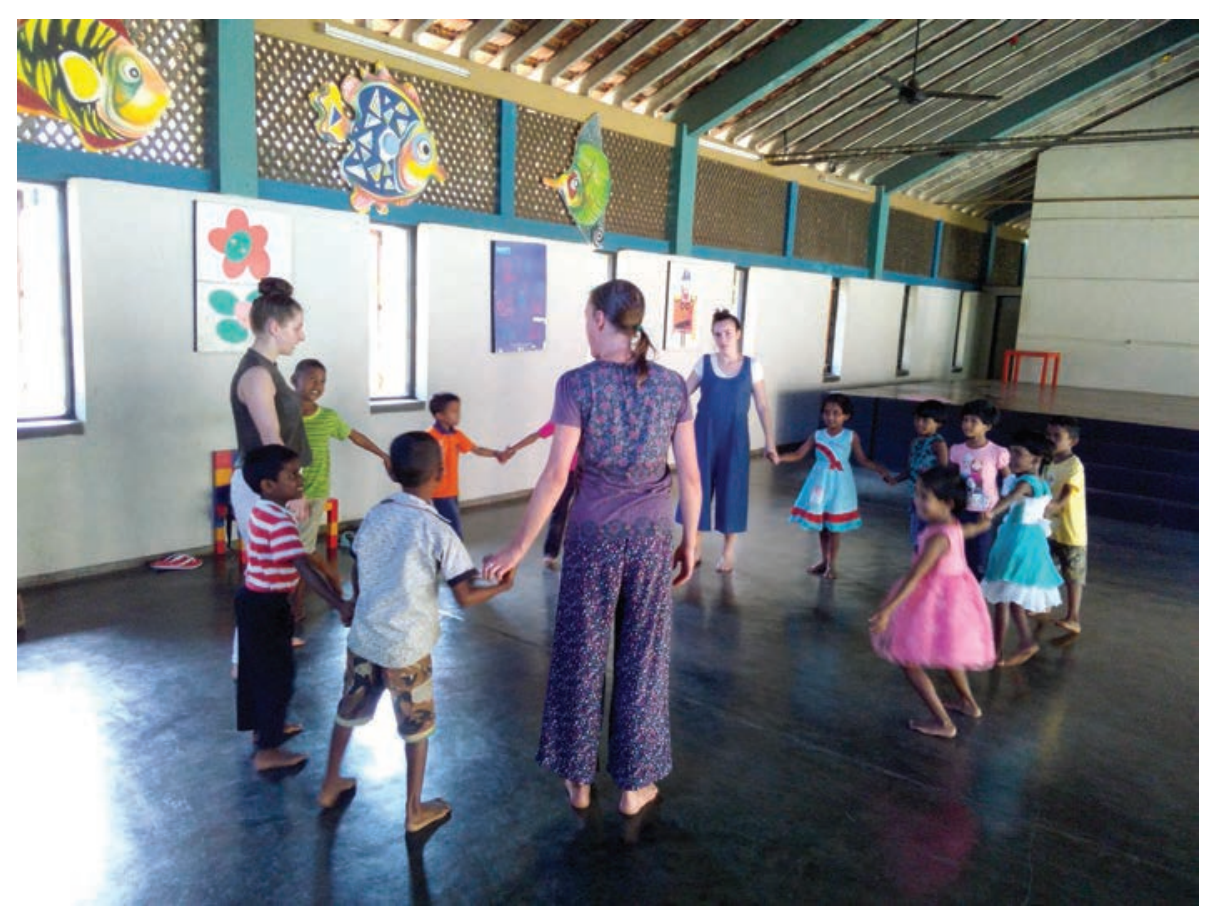

Global Hope outreach program, SOS Village, Galle, Sri Lanka 2015.

Liverpool Hope University has collaborated for over a decade with SOS Villages Sri Lanka, as part of its annual Global Hope charity program. Initially founded by Austrian philanthropist Hermann Gmeiner in 1968, there are currently fifteen SOS villages spread across South East and East Asia which care for over 36,000 children. Our own university has collaborated for almost a decade with SOS Villages UK and Sri Lanka is one of several global establishments that both students and staff return to each year. Founded in 1990, the SOS Children's Village in Galle is Sri Lanka's longest standing organisation, and is home to 104 children between the ages of 5 and 15 years. The Global Hope program, run by Liverpool Hope University, is a long established project, that recruits our undergraduate students to deliver Sports and/or Arts based activities as a summer camp in order to teach English skills, and to build self-esteem amongst orphans living in these SOS villages. The program is facilitated by university teaching staff and personnel and runs for three weeks in August, adopting an English language focus with communication being a key theme of all activities.

Global Hope teaching activities normally take place outdoors and run throughout morning and afternoon sessions from Monday to Friday with activities often being repeated for different groups of children. Each year the SOS Village visits are monitored and reviewed, with each village specifying their particular requirement from the University. In addition Hope students and staff can lead development activities for the 'mothers' linked to healthy eating, child wellbeing and learning. The mothers are care staff who live and work in the village, maintaining the children's everyday domestic 


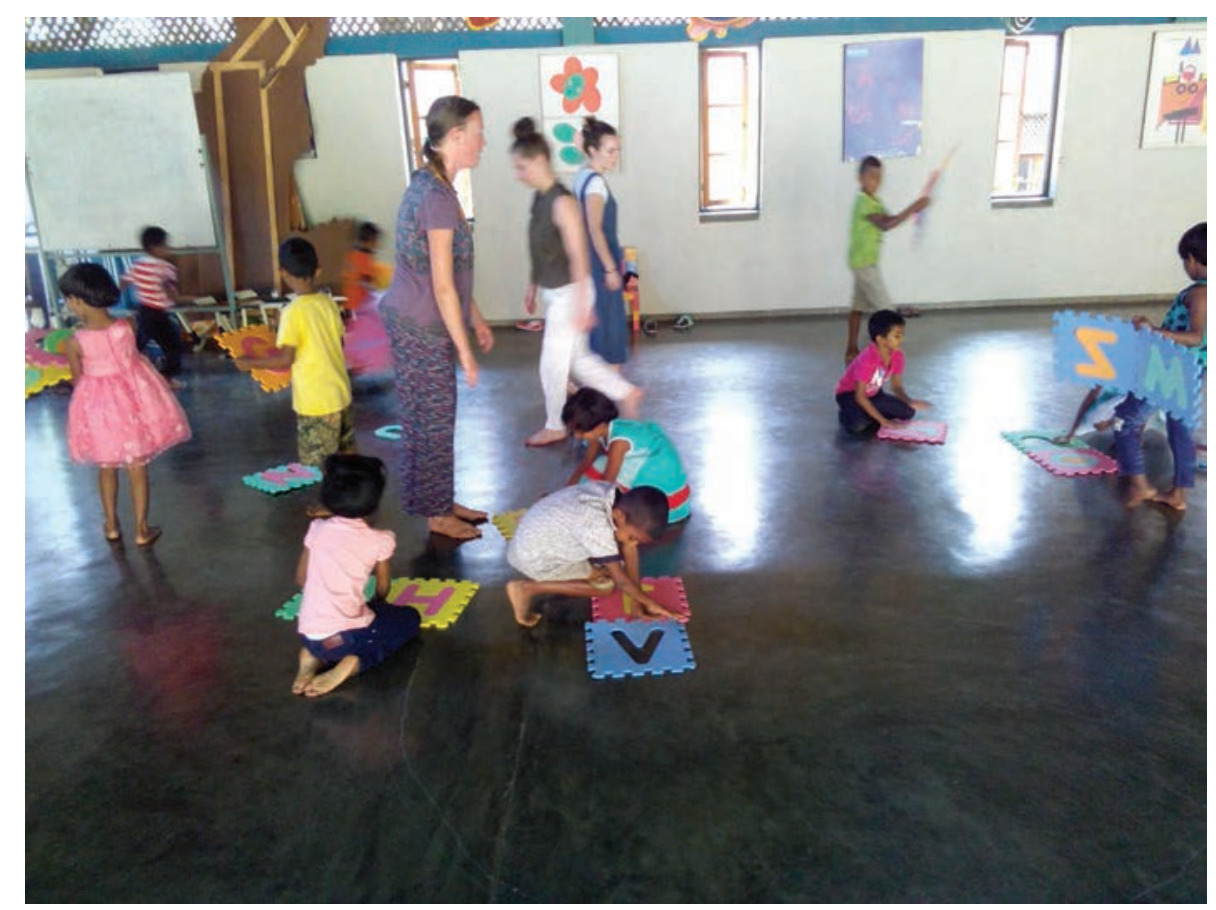

Global Hope outreach program, SOS Village, Galle, Sri Lanka 2015.

activities and running their shared housing units. In addition to providing residential school education, the Centre also runs essential social outreach programs including a highly progressive drop in antenatal clinic and free family counselling service, as well as hosting international schemes throughout the year. A wider overview of the Centre's mission aims responds to the vast spectrum of southern Sri Lanka's social and economic problems. The children's own short histories are often highly complex, where widespread poverty across the region may force parents to seek work abroad. In 1998 UNICEF estimated that some 36,000 children were living without parents, leaving families with young children in particular exposed to exploitation. The catastrophic Tsunami that swept across South Asia in 2004 is still very much visible today. Despite initial swift international aid, the ecological effects of this Tsunami can be seen to have decimated family structures, with mass life loss as well as earnings, where most of the local industry is based on either tourism or fishing. This is doubly impacted upon where, hidden far away from Galle's palm swept beaches bestowing the island's sand and surf attractions, there lurks a far darker tourist industry affecting vulnerable children, as child sex exploitation remains a threat to those without immediate family protection.

Many of the SOS Village staff are highly trained educationalists and social workers who live alongside the children and through whose patient and highly skilled guardianship, each individual child adapts readily to their newly found environment, housed in comfortable living spaces with clear routine structures and round the clock care. Although our time here is relatively limited, the Global Hope program is fully 
embedded in the children's annual calendar, the students' own availability coinciding with the Sri Lankan school holiday season, meaning that any teaching agenda needs to be firmly placed in the domain of fun and creative learning. The project aim of Global Hope in Sri Lanka is to develop an understanding in our own students, of the value of developing children's literacy and comprehension skills in English using kinaesthetic learning and participatory methods, and classes are designed using many creative methods to develop conversational skills and also to improve memory skills in learning new English vocabulary. Our work is twofold - firstly to expose children to a new approach of learning a new language skill, and secondly to promote creative arts education. Whereas many modern education teaching models can be seen to focus on academic achievement, the role of informal education provides students with the opportunity to develop their own ideas, morals and values while focusing on personal as well as collective identity. Many of the games and learning tasks outlined below emphasise the development of children's personal goals though 'provid(ing) an effective way to influence individuals' behaviour and equip them with knowledge to develop social supports for enhancing resilience' (Feng 2018: 3).

The first impression of arriving into the SOS Village is of that of contented industry, with lively children of all ages occupying colourful shared brick houses, greeting our arrival with a steady stream of chatter and frantically waving arms out windows and doors. This is my second trip to the SOS Village, having spent the previous year at a sister SOS Village in Pilyandala, just outside Colombo, and the familiar colourful brick roofing and immaculate gardens surrounded by jumbled playground equipment immediately make the group feel welcome. At its core, the daily running of SOS Village life encompasses a holistic pedagogic approach that covers every aspect of the children's educational welfare, from gentle morning stretches, daily chores, mealtimes, reading times, playing times and lesson times to general teenage hang out times. I am struck by the regularity and ease that is so embedded within the quotidian rhythms of the SOS Village, where children fluently shift gears from domestic routines to formal learning practices to social spaces. My frequent daily walks between our spacious accommodation and the classrooms and kitchen are illustrated by drying vats of brightly coloured chillies and turmeric spread amongst stretched out rainbow laundry and chalked passages of hopscotch along the garden pathways. Research suggests that creating social emotional learning environments, whereby students can develop positive relationships with adults, aids in their development of resilience. As Hymel states of holistic education, belonging to such an inclusive, caring environment 'provides a foundation for building and sustaining learning relationships that lead to academic success' (Hymel, 2007:21). Similarly, Hymel suggests how 'Social emotional learning environments have to ability to manage emotions, develop caring attitudes towards each other and handle challenging situations effectively (ibid:23). Within the governing structures of the SOS Villages, children from a young age are more likely to bond with the 'mothers' within each established household, whilst identifying a separate learning agenda with their own teaching staff. Similarly, the older children from ages 14-17 are placed in separate youth accommodation and are encouraged to take more responsibility such as local part time jobs and attending extra curricular classes in music and other creative arts. 
Interestingly, this year the small cohort of second and third year Liverpool Hope University students that have been recruited all share a similar degree program of Performing Arts. This naturally forms a strong identity for the program and the lesson plans are designed to prioritise kinaesthetic learning methods while implementing English speaking and writing skills. Below is a summary of some of the lesson materials the group developed over the two week period, as recorded by one student:

\section{"Day 2 Monday $19^{\text {th }}$ August"}

We conducted our first classes today. We were unsure of what to expect with each class as we didn't know if they knew any English at all, but we planned some activities yesterday that we thought we might be able to do with the children and it appeared to go well.

First of all we got the children with the help of the kindergarden teachers here to make name badges out of the stick on letters we'd brought. We got them to say their names, then with the large foam letters, we got them to put them in the order of the alphabet saying each letter. We had to sing the $\mathrm{ABC}$ song quite a few times up to each letter as we got nearer to the end. Most of them seemed to know the song quite well. We also asked them to stand by the letter of the alphabet that their names begin with. After this we gave them several letters each and put them into groups, then asked them to draw a picture of a word that began with each letter. When they had finished, they had to tell us what they had drawn. Next they drew around their hand and had to tell us one thing about themselves for every finger on their hand, so five facts like what colour they liked. We repeated the same lesson with the next class as they were only one year older.

\section{"Day 3, Tuesday $20^{\text {th }}$ August"}

Today we had to teach two groups of grade 3 children. They are about 8 years old and very shy when speaking English, a lot less confident than the other groups that we have had. We started off with getting them to make their name badges then the alphabet again out of the large foam letters. We gave them a card each from the opposite card box and asked them to show us an action to describe the card they had, then we lay all the cards on the floor and in their pairs, they had to find matching opposite cards then tell us what they had. Then we got them to make animal masks and tell us about the animal, then in a circle we all pretended to be the animal, moving and making the correct noises for each child's mask. We also sang head, shoulders, knees and toes with them, and If you're happy and you know it. Towards the end, I read the children a story of the Lion King, but found the words too complicated and the story too long, so I adapted it to make it simpler and easier for them to understand.

In the afternoon, we had two grade 8 groups. Although they were a bit shy when it came to speaking and thinking for themselves, they had a good understanding of written English, with the ability to spell out words using the Lexicon cards. They were also great fun and loved playing the fruit salad game which we adapted to colours and the rainbow. We also created scenes such as in a restaurant and on a bus, and one person 
had to leave the room whilst the scene was decided and set, then when they re-entered they had to use three words to describe what we were doing. They were very good at that game. They also liked the game where we all sat in a circle and were given a number, number one had to say I accuse number and say a number from the circle. That person with that number then had to stand quickly and accuse another number etc etc. Once a person didn't respond, the person had to move to the end and everyone moved round a place, thus taking on a new number.

\section{"Day 3, Wednesday 21 August"}

Today's class in the morning was the most difficult class we've had. There were 3 girls and 3 boys and it was very difficult to get them to speak in English at all. We threw a ball of wool from one to the other saying the name of the person they were throwing to. The wool thrown made a spider web between us all. We used the lexicon words and from the words they had formed, we got the children to make a story out of the words, from the story, a song, then a dance/movement with the song. I had created word searches for them which they enjoyed dong and we also had a competition where the two teams had to decide out of two words, which spelling was the correct one, if it was number 1 , they had to stand on the side of the room where number one was, and the same for number 2. We also played a game where one child was blindfolded although we asked them to volunteer for this as we weren't aware of their backgrounds and if they would be comfortable in being blindfolded. The other children then had to direct the blindfolded person to the lollipop we'd placed at the other end of the corridor. We gave them simple commands such as start, left, right, one, two or three steps and stop and moved obstacles each time for each child to keep it interesting and challenging for them.

Due to the emphasis on direct participation, inclusivity, verbal and non verbal communication and expressivity, the arts can provide methods of teaching that arguably enable a number of students to perform well academically and become engaged in learning (Robinson 2017). From the outset, we quickly adapted our initial leaning emphasis from focusing on English vocabulary and sentence phrasing more towards collative singing and call and response activities to generate confidence. The teaching and learning frameworks that we adopt are firmly rooted in creative pedagogic approaches as based on kinaesthetic learning methods. Some of the main aspects of learning include the following: collective energy, rhythmic manipulation, physical coordination and spatial design through sensory contact, all of which contribute to a more holistic learning environment. Stinson suggests how integrating creative arts into the formal curriculum benefits those who are unable to conform to traditional teaching styles that strictly involve sitting, listening and writing (Stinson 2004). Through their engagement with the above tasks, students could be seen to engage their cognitive skills such as long term memory, attention and visual and auditory processing, as well as developing cooperative work and problem-solving tasks. The results of these learning activities can be viewed in a short documentary filmed on location 'Global Hope Sri Lanka': https://www.youtube. com/watch?v=E2fFW1pFnSE). 
Ken Robinson questions the status within formal primary and secondary education of the arts in the UK, suggesting how "(w)e are not advocating creative and cultural education as alternatives to literacy and numeracy, but as equally relevant to the needs of this and of future generations", further advocating the need to prioritize creative teaching and learning in order to enhance literacy and numeracy rather than regarding this approach as oppositional (Robinson 1999:13). By integrating creative arts approaches with the meta-practical aims of learning a new language, the above lesson materials allowed for a receptive learning environment, and once many of children's initial barriers of shyness were overcome, lessons became centred around rhythmic exercises that emphasised repetition through call and response alongside gestural movement and song. These methods follow a constructivist approach to pedagogy where the physical embodiment of the image or word allows children to take ownership over their learning, while engaging widely with each other as also the young student teachers. The emphasis in our lessons is on inclusivity and individual agency - developing rhythm and song as a way of memorising quite complex sentence structures as also an acute awareness of group dynamics through clear spatial structures. Pre-breakfast meetings in the staff quarters allow for regular reviews of each day, implementing changes in lesson plans before the rising heat and humidity take over. Within their own arts education model in the university, the students are encouraged to deliver a body focused approach to learning through their formal undergraduate degree pathways in both Drama and Dance. Through both taught practical seminars and work placements, they are also equipped with training on the dissemination and delivery of both subjects in a range of contexts, developing a series of lesson plans targeted for specific constituent groups as well as gaining training of the ethics of participation, funding opportunities and health and safety issues surrounding facilitating workshops in a diverse range of community settings. These assignments encourage our students to consider types of ground rules/boundaries, to explore inclusion and participation, and also explore policy and procedures before actually entering the professional work- or community establishment.

These and other evaluative approaches encourage a sense of democracy within the group and I enjoy witnessing a progressive sense of ownership from the students as both their own confidence and their teaching initiatives develop throughout the weeks. Our apparent efforts with the children start to become audibly evident in the first few days as we are greeted each morning with chirpy rounds of English nursery rhymes with Bob Marley songs interspersed! Evenings are spent in reverse roles as the children teach us some local dances, patiently correcting our sloppy elbows and counting rhythmic steps with slow precision. As our time at the village draws to an end, I reflect on some of the intrinsic values that this immersive project may have brought on both sides. Certainly, the learning shift in my own students is significant and will provide an invaluable foundation for their continuing career pathways, where a considerable number of graduates from Liverpool Hope University may choose to work in primary or tertiary education. For the children's part, the hope is that they will have adapted to new learning territories, and have overcome their fears of speaking a foreign language. The project also gives both parties the chance to exchange language skills, to share new games (the long standing British Isles tradition of 'Rounders' now sits in a comfortable 
second to Sri Lanka's national favourite sport on the Galle cricket playing fields!) and most importantly, to share between us the everyday activities of eating, singing, praying and reading that make up daily life in an SOS Village. Edmund O'Sullivan offers a definition of Transformative Learning in relation to overall cognitive development:

Transformative learning involves experiencing a deep, structural shift in the basic premises of thought, feelings, and actions. It is a shift of consciousness that dramatically and irreversibly alters our way of being in the world. Such a shift involves our understanding of ourselves and our self-locations; our relationships with other humans and with the natural world, our understanding of relations of power in interlocking structures of class, race and gender, our body-awarenesses, our visions of alternative approaches to living, and our sense of possibilities for social justice and peace and personal joy (O'Sullivan: 2007).

O'Sullivan's views are central to the notion of creative pedagogy and transformative learning in promoting an awareness of individual capacity as it relates to the wider environment. The Global Hope projects are unique, not only in terms of cross Department collaboration, where both students and staff may represent quite a large diversity of subjects which affords cross disciplinary dialogue to evolve in relation to different teaching approaches. Furthermore, the timing of the projects corresponds with a break in our usual academic calendar which often enables a more democratic learning environment between staff and students, offering a supportive and salient peer learning environment.

Our final afternoon heralds the start of monsoon season and the sporadic showers that have interrupted our daily walks are gradually replaced by a constant deluge. A gale force wind rudely interrupts our final sing-a-long, uprooting a twenty foot palm tree within dangerous reach of the school hall and knocking out the electricity. While this would be enough to send children screaming for cover and interrupt studies for days in England, the children here barely notice the climactic event, a strong reminder of the islanders' resilience to erratic weather. Our small group gradually thins out over the final weekend as some of the students choose to travel to Kandy to spend their last few days exploring tea plantations and an elephant orphanage, while others drift south to the beaches, our pockets stuffed with letters and paintings from the children. My own return to the UK rapidly becomes clouded with the impending arrival of new first year students, and the frantic preparations of the new academic term. Our group agrees to meet in a few weeks to exchange photos and stories of our travel and I have already recruited three out of four students to come and deliver a seminar on their teaching experiences abroad for the University's Foundation Hour, a weekly meeting where both staff and students take time to pause and reflect on important issues beyond the curriculum. A fourth student has already expressed a firm desire to return to Galle and to remain at the SOS Village for a prolonged period of volunteering when she graduates next summer. My staff colleague has just completed her documentary of our experiences in a short film, which we look forward to sharing with our new students this November, as we start to recruit a new project group for next year's program. 
Global Hope is looking forward to continually supporting current partnerships and to expanding to meet new challenges with new partners in many new locations. For further information please contact globalhope@hope.ac.uk.

\section{About the Author}

Dr Rachel Sweeney is a practicing movement artist with a background informed by Butoh and its sister form, Body Weather. Her independent performance work has been funded by the Arts Council of Ireland, the Arts and Humanities Research Council, Dance in Devon and London Arts Board. Her teaching specialisms include intercultural theatre training and site based performance and she is currently a Senior Lecturer and Head of Dance at Liverpool Hope University. International posts include the University of Visual and Performing Arts in Colombo, Sri Lanka where she steers an ongoing research program in cross cultural performance training and a Visiting Fellowship for the Humanities Research Centre at the Australian National University

\section{References}

Anderson, B. (2016). 'Philosophy for Children: Theories and Praxis in teacher education'. Routledge, UK. Feng, S., Hossain, L. and Paton, D. (2018). Harnessing informal education for community resilience. Disaster Prevention and Management: An International Journal, 27(1), pp. 43-59.

O’Sullivan E., Hathaway M., and O’Neill E. (1999). Transformative Learning: Fostering Educational Vision in the 21st Century. Zen Books, UK.

O'Sullivan, E. (2007). 'Finding Our Way in the Great Work' lecture presentation (Sustainable Education CPD course, Schumacher College, Devon, Nov 2007)

Robinson (1999). 'All Our Futures: Creativity, Culture and Education' Report to the Secretary of State for Education and Employment the Secretary of State for Culture, Media and Sport. NACCCE report http:// sirkenrobinson.com/pdf/allourfutures.pdf.

Stinson, S. W. (2005). The Hidden Curriculum of Gender in Dance Education, Journal of Dance Education, $5: 2,51-57$.

Stinson, S. W. (2010). Questioning Our Past and Building a Future: Teacher Education in Dance for the 21st Century. Journal of Dance Education, 10:4, 136-144.

\section{Online Reference}

'Global Hope Sri Lanka' (video editor Carly Rice featuring Rachel Sweeney and participants of Global Hope 2015): https://www.youtube.com/watch?v=E2fFW1pFnSE). 